\title{
VÝZVA, NEBO NEMOŽNÁ MISE? TRANZICE K ONLINE VÝUCE V DOBĚ PANDEMIE COVID-19 OČIMA VYSOKOŠKOLSKÝCH UČITELŮ
}

\author{
CHALLENGE OR MISSION IMPOSSIBLE? \\ THE TRANSITION TO ONLINE TEACHING \\ DURING THE COVID-19 PANDEMIC \\ THROUGH THE EYES OF UNIVERSITY \\ TEACHERS
}

\author{
KLÁRA ŠEĎOVÁ, \\ BARBORA NEKARDOVÁ, \\ KATARÍNA ROZVADSKÁ
}

\begin{abstract}
Abstrakt
$V$ této studii se zabýváme problémem tranzice od prezenčni k distančni výuce ve vysokoškolském prostredî $v$ době pandemie Covid-19. Vycházime z analýzy 34 bloubkových polostrukturovaných rozhovoru s učiteli Filozofické fakulty Masarykovy univerzity, v nichž tito učitelé reflektovali sviij prìstup k distanční online výuce v době pandemie Covid-19. Ukazujeme, že zpissob, jakým učitelé k výuce pristoupili, silně souvisí s jejich pojetím výnky a tím, jak konstrunji koncept dobré vysokoškolské výuky. Na základě analýzy rozhovoru rozlišujeme dva polárni typy učitelu. Prvnim typem jsou funkecionalisté, kterí se koncentruji na predáni znalosti a dovedností studentum. $V$ dobè pandemie s využitím uvážlivé pedagogické analýry usiluji o to, co nejlépe substituovat jednotlivé složky prezenčni výuky pomoci digitálnich nástroju a aplikací. Domnivají se, že kevalitni online výuka je náročná, avšak proveditelná a potenciálnè prínášjicí novou kvalitu do vysokoškolského vąélávání. Drubým identifikovaným typem jsou autentisté, kteř́ výnku chápou jako vytváreni znalostí a dovednosti v procesu autentické komunikace mezi učitelem a studenty. Tito učitelé se domnivaji, že pomoci online nástroju neni možné preženčni výuku adekvátnè substituovat a tranzici k. distančni výuce vnimají jako zásadni obroženi kvality a obecně obroženi posláni vysokoškolskébo vadèlávání.
\end{abstract}

Klíčová slova

vysokoškolské vąěláváni, digitálni technologie, distančni výnka, Covid-19, učitelská pojetí výnky 


\begin{abstract}
In this study, we address the research problem of transitioning from face-to-face to distance teaching in a university setting during the COVID-19 pandemic. We based our study on an analysis of 34 in-depth semistructured interviews with teachers of the Faculty of Arts at Masaryk. University, in which these teachers reflected on their approaches to online distance teaching during the COVID-19 pandemic. We show that the way the teachers approached the teaching was strongly linked with their conception of teaching and the way they construct the concept of good higher education. According to the analysis of the interviews, we distinguish two polar types of teachers. The first type are functionalists, who focus on passing on knowledge and skills to students. During the pandemic, using judicious pedagogical analysis, they strove to best replace the various components of face-to-face teaching with digital tools and applications. They believe that quality online teaching is challenging, but feasible and potentially bringing new features to higher education. The second type identified were authenticators, who understand teaching as a creation of knowledge and skills in the process of authentic communication between teacher and students. These teachers believe that online tools do not make it possible to adequately replace face-to face classes and perceive the transition to distance learning as a major threat to quality and to the mission of higher education in general.
\end{abstract}

\title{
Keywords
}

higher education, digital technologies, distance education, COVID-19, teaching approaches

\section{Úvod}

Integrace digitálních technologií do vysokoškolské výuky představuje dlouhodobě a pozvolna probíhající proces, na němž až do nedávné doby někteří učitelé participovali ochotně, jiní méně ochotně či vůbec (Naylor \& Nyanjom, 2020). Na jaře 2020 však v důsledku pandemie covid-19 došlo $\mathrm{k}$ uzavření vysokých škol, přičemž digitální technologie se staly základním nástrojem k zabezpečení distanční formy výuky. Tato studie si klade za cíl reflektovat, jak tuto náhlou tranzici vnímali ti, na jejichž bedra byla naložena, tedy vysokoškolští učitelé. Naším záměrem není přinést technickou zprávu o tom, jaké aplikace učitelé používali či jaké množství času výukou trávili, nýbrž rozkrýt jejich subjektivní vnímání vzniklé situace a ukázat, jak o své výuce uvažovali a jaké strategie volili $\mathrm{k}$ jejímu zajištění. Vycházíme přitom z předpokladu, že zásadním faktorem, který ovlivnil využívání technologií v pandemii, je učitelovo subjektivní pojetí výuky. V této studii proto zkoumáme, jak se pojetí výuky a subjektivní přesvědčení učitelů o tom, co je kvalitní vysokoškolská výuka, promítly do jejich zacházení s digitálními technologiemi v pandemii. 


\section{Technologie jako příslib kvality ve vysokoškolském vzdělávání}

Jak uvádějí Liu et al. (2020), implementace technologií se děje s cílem zlepšit a pozitivně transformovat vzdělávání na univerzitách. V tomto smyslu se integrace technologií stává součástí úsilí o zajištění kvality výuky. Na otázku, jaké charakteristiky má kvalitní vysokoškolská výuka, přitom existuje řada odpovědí (viz např. Bain, 2004; Devlin \& Samarawickrema, 2010; Hativa et al., 2001; Lowman, 1995; Šed’ová et al., 2016). Jakkoli se jednotlivé koncepty dobré výuky liší, lze vysledovat dva leitmotivy, ohledně nichž panuje všeobecná shoda. Je to nakládání se vzdělávacími obsahy na straně jedné a interakce se studenty na straně druhé. V prvním bodě jde o zajištění kvalitního kurikula, studijních materiálů a jejich jasné a podnětné prezentace směrem ke studentům. Ve druhém bodě jde o to, aby interakce se studenty vedla k posílení jejich motivace a zájmu o studium. Jako dobrá vysokoškolská výuka je $\mathrm{v}$ současné době chápána ta, která je zaměřená na studenty (student-centred), to znamená, že vychází z jejich potřeb, staví je do pozice spolutvưrcủ vědění a povzbuzuje jejich aktivitu, nezávislé myšlení a kritičnost (viz např. Kember \& Kwan, 2000; Trigwell \& Prosser, 1996). Opakem výuky zaměřené na studenty je výuka zaměřená na učitele, v níž je učitel dominantním nositelem znalostí, jež předává studentům, kteří jsou chápáni jako jejich víceméně pasivní prř́jemci.

Nabízí se otázka, do jaké míry jsou očekávání vztahovaná směrem k technologiím a jejich potenciálu zkvalitnit výuku realistická. Mohou skutečně transformovat zpo̊soby nakládání se vzdělávacími obsahy a interakce se studenty? Liu et al. (2020) v rozsáhlé syntetické studii konstatují, že e-learningové technologie jsou na univerzitách stále více rozšířené, avšak pedagogické benefity $\mathrm{z}$ nich plynoucí dosud nejsou plně zužitkované. Ačkoli tedy vysoké školy investují do vybavení i do školení učitelů, jejich transformační potenciál technologií nebývá naplněn (Schneckenberg, 2009) a institucionální úsilí o technologiemi tažené pedagogické inovace často selhává (Porter \& Graham, 2016).

Klíčovými aktéry zapojování technologií do výuky jsou beze sporu učitelé. Dlouhodobě se diskutuje jejich připravenost a ochota využívat technologie pro vyučování a učení. Almerich et al. (2016) uvádějí, že kompetence učitelů k zapojování technologií jsou tvořeny dvěma podmnožinami. První podmnožinu tvoří kompetence technologické (obsluha technologií, využívání aplikací), druhou podmnožinu kompetence pedagogické (promyšlené využití technologií ve prospěch didaktických cílü). Vysokoškolští učitelé jsou poměrně pokročilí co do technologických kompetencí, jejich kompetence pedagogické však pokročilé nejsou (Almerich et al., 2016). V souladu s tímto Downing a Dyment (2013) zjistili, že mnoho vysokoškolských učitelů, kteří se se cítí vysoce kompetentní a sebejistí v běžné výuce tváří v tvář, prožívá 
frustrující pocity nekompetentnosti, mají-li přejít na e-learning. Jejich pedagogické kompetence pro práci s technologiemi nejsou dostatečně rozvinuté, což vede k nízkému pocitu učitelské sebeúčinnosti. Pochopitelně existují také učitelé, kteří jsou ohledně technologií entuziastičtí a futurističtí, větší část učitelů je však ve svých postojích spíše ambivalentní či přímo odmítavá (Naylor \& Nyanjom, 2020).

\section{Nouzová distanční online výuka v pandemii}

Výše jsme uvedly, že vrůstání digitálních technologií do vysokoškolského vzdělávání představuje dlouhodobě probíhající proces. Na jaře roku 2020 však nastala ruptura $\mathrm{v}$ dosud pozvolném vývoji. $\mathrm{V}$ důsledku opatření pro zvládání pandemie covid-19 došlo k masivnímu přechodu na distanční vzdělávání, přičemž se právě digitální technologie náhle staly klíčovým nástrojem, který měli pedagogové $\mathrm{k}$ dispozici. Tento bezprostřední obrat je označován jako nouzová distanční výuka (emergency remote teaching) (viz např. Bozkurt \& Sharma, 2020; Cameron-Standerford et al., 2020). Zatímco dříve byly online kurzy pro učitele i studenty dobrovolnou záměrnou volbou a spuštění těchto kurzů předcházela intenzivní př́prava, $\mathrm{v}$ nouzovém stavu nebyl prostor pro plánování ani pro zvažování, zda k online výuce přistoupit (Cameron-Standerford et al., 2020). Jak uvádějí na základě mezinárodního dotazování mezi vysokoškolskými učiteli Scherer et al. (2021), drtivá většina učitelů byla svými školami k přechodu na online výuku explicitně vyzvána, přičemž pro tuto tranzici dostali v průměru necelých sedm dní na př́pravu. Cutri et al. (2020) upozorňují, že ačkoli mnozí akademici měli zkušenosti s online výukou, tyto zkušenosti nepostačovaly ve chvíli, kdy byla vynucena okamžitá tranzice probíhající v traumatických podmínkách a zároveň nebylo zřejmé, zda jde či nejde o dočasnou záležitost, která záhy pomine.

V této chvíli máme $\mathrm{k}$ dispozici zatím jen omezené množství empirických zpráv o tom, jak byli učitelé na rupturu připraveni a jak ji zvládli. Scherer et al. (2021) na vzorku 739 vysokoškolských učitelů z 58 zemí zjišt’ovali jejich připravenost na online výuku v době pandemie. Zjistili, že jako vysoce př́ipravení se cítili ti učitelé, kteři disponovali předchozí bohatou zkušeností s online výukou, a proto byli sebejistí ohledně svých dovedností a zároveň cítili institucionální podporu. Těch však byla ve vzorku menšina. Většina učitelů bud' nebyla sebejistá, nebo u nich absentovala institucionální podpora, př́padně docházelo ke kombinaci obou těchto negativních faktorů.

Rychlé mezinárodní šetření provedli rovněž Marek et al. (2021). Na vzorku 418 akademiků, kteří $\mathrm{v}$ době pandemie konvertovali své kurzy z prezenční do distanční online podoby, zkoumali zkušenosti s touto konverzí. I v tomto výzkumu se prokázal pozitivní vliv předchozího využívání online 
výukových technologií. Bez ohledu na míru své technologické zběhlosti respondenti uváděli, že distanční online výuka jim přinesla větší časovou zátěž a větší míru stresu v porovnání s klasickou prezenční výukou. Tento nález potvrzuje, že pandemická tranzice byla pro učitele náročná až traumatizující.

V českém prostředí se zatím odborná reflexe vysokoškolské výuky v pandemii omezuje na dílčí př́ipadové studie jednotlivých kurzů (Duschinská \& High, 2020; Krátká \& Zemanová, 2020). Vedle toho máme první sondy založené na tom, jak o výuce v jarním semestru 2020 vypovídali studenti. Fritzová (2020) získala dotazníková data od 145 studentů historických kateder z různých univerzit a fakult. Výsledky naznačily nespokojenost studentů s výukou v jarním semestru 2020. Studenti vypovídali o potřebě pravidelné synchronní online výuky, s takovou výukou se však setkalo jen $20 \%$ z nich. Ostatní reportovali, že učitelé komunikovali přes e-mail či zadávali úkoly prostřednictvím e-learningových portálů.

Podolská (2021) provedla kvalitativní šetření na vzorku osmi studentů Filozofické fakulty MU. Ti vypovídali o různých kurzech, jimiž na jaře 2020 prošli na jedné katedře. I v takto úzce vymezeném prostředí se ukázala velká diverzita zkušeností, které studenti získali - někteří učitelé přistoupili k synchronní online výuce, jiní nahrávali videozáznamy přednášek, další poskytovali pouze písemné materiály. Největší skupina předmětů byla do distanční podoby překlopena tak, že učitelé nepravidelně poskytovali studentům písemné materiály a zadávali jim úkoly. Souhrnně lze říci, že dostupné indicie naznačují, že se vysokoškolští učitelé postavili k distanční výuce $\mathrm{v}$ pandemii velmi různorodým způsobem. Tato diverzita př́ístupů je nepochybně výzvou pro podrobnější zkoumání.

\section{Učitelská pojetí výuky ve vztahu k využívání digitálních technologií}

Odborníci zkoumající integraci digitálních technologií do vysokoškolské výuky dlouhodobě upozorňují na to, že rozhodování ohledně využívání technologií významně ovlivňují subjektivní přesvědčení učitelů a jejich pojetí výuky. Jinými slovy to, jak učitel vidí svoji vlastní výuku, má dopad na to, jaké technologie a jakým zpo̊sobem (a zda vůbec) je učitel bude do výuky zapojovat (Ertmer, 2005). Jde o logické spojení, nebot' učitelovo pojetí výuky je základem pro učitelovo uvažování o pedagogické skutečnosti i pro jeho pedagogické jednání (Mareš et al., 1996). Jde o ustálené implicitní konstrukty učitelovy mysli, které se projevují ve výukových situacích a ovlivňují kvalitu a účinnost výuky (Koubek, 2018). 
Zatímco v českém kontextu dosud nebylo učitelovo pojetí výuky zkoumáno ve vztahu k využívání digitálních technologií ve vysokoškolském prostředí, v zahraničí některé takto zaměřené studie existují. Obecně podle syntetické přehledové studie sepsané Liu et al. (2020) platí, že konstruktivistické pojetí výuky - ve smyslu facilitace konstrukce poznatků namísto jejich přenosu od vyučujícího ke studentovi - je faktorem, který posiluje pravděpodobnost integrace technologií učitelem. $\mathrm{K}$ dispozici máme dále několik kvalitativních studií, které se pokoušejí o plastičtější vykreslení toho, jak se subjektivní učitelská přesvědčení a pojetí výuky propisují do práce s online technologiemi.

Englund et al. (2017) longitudinálně sledovali, jak devět učitelů jedné fakulty využívá digitální technologie ve výuce. Ukázalo se, že učitelé, kteří měli na počátku menší zkušenosti $\mathrm{v}$ práci s technologiemi, sdíleli koncept výuky zaměřené na učitele. Naopak technologicky zkušení učitelé tendovali více $\mathrm{k}$ pojetí výuky zaměřené na studenty. $\mathrm{V}$ průběhu více než desetiletého sledování těchto učitelů docházelo k postupným změnám, které byly větší u učitelů s menší zkušeností na počátku výzkumu. Tito učitelé paralelně s tím, jak se učili využívat technologie, posouvali také své pojetí výuky, a to směrem $\mathrm{k}$ prŕístupu orientovanému na studenty.

Heinonen et al. (2019) analyzovali reflektivní deníky 18 univerzitních učitelů zahrnutých do programu na rozvoj technologicky podporované výuky. Identifikovali čtyřri různá pojetí integrace technologií: (1) aktivní technologie jsou vnímány jako slibný a fascinující nástroj př́nášející zřetelné benefity, učitelé sami sebe popisuji jako odvážné a intuitivní, jsou ochotni v práci s technologiemi riskovat a hledat nové cesty; (2) adaptivní - technologie jsou vnímány jako potenciálně př́nosné, pokud jsou v souladu s pedagogickými potřebami učitele, tito učitelé vyžadují technickou podporu i podporu kolegů, aby technologie uvážlivě integrovali; (3) obezřetné - technologie jsou nazírány jako konkurence pro tradiční vyučování, je zdůrazňován jejich omezený přínos a nedostatky v porovnání s výukou tváří v tvár̆, tito učitelé jsou v zapojování technologií stř́ídmí; (4) zdrženlivé - technologie jsou pojímány jako hrozba pro vyučování a učení, tito učitelé jsou rezistentní vůči jejich zapojování, nechtějí si osvojovat technologické kompetence, na technologicky aktivní kolegy pohlížejí kriticky.

Jääskelä et al. (2017) realizovali studii založenou na rozhovorech s 18 učiteli, kteří se účastnili univerzitního programu na podporu výuky s technologiemi. Identifikovali čtyři různá pojetí technologií: (1) klíčový nástroj pro individualizaci tempa studia, způsob, jak nabídnout studentům flexibilní a inspirující prŕíležitosti k učení; (2) podpưrný nástroj pro aktivní a interaktivní učení stimulující aktivní čtení, práci na kreativních úkolech, využívání kritického myšlení, interakce s ostatními; (3) nástroj pro integraci a hodnocení učení umožňující rozvíjet dílčí kompetence studentů a integrovat je 
do rámce teoretického a praktického poznání v daném oboru; (4) nástroj pro změnu kultury učení, který posiluje autonomii studentů, autenticitu a smysluplnost učení, rozvoj osobních zájmů a potřeb studentů.

Po nástupu pandemie využil koncept pojetí výuky Ramlo (2021), který na vzorku 78 respondentů zkoumal prostřednictvím Q metodologie postoje akademiků $\mathrm{k}$ nucenému přechodu na online výuku. Identifikoval tři rámcové typy pohledu na situaci: (1) technologičtí fanoušci, kteří rádi vyučují, optimističtí ohledně online výuky v pandemii; (2) přetížení učitelé, kteří obtîžně kombinují své výukové povinnosti s rodinným a osobním vytížením v pandemii; (3) učitelé vnímající online výuku jako limitovanou, především v oblasti interpersonální stránky učení a praktické výuky.

Výše uvedené studie ukazují, že pojetí výuky souvisí se subjektivně vnímanou ochotou a připraveností s technologiemi pracovat. Kromě toho si učitelé vytvářejí jemnější chápání toho, jaké jsou potenciální - pozitivní i negativní - dopady užívání technologií a jakou roli mohou technologie ve výuce sehrávat. Je velmi pravděpodobné, že diverzita v pojetích výuky vyvolává také diverzitu v reálné práci s technologiemi. Jinými slovy, různí učitelé zapojují technologie různým zpo̊sobem, a to v důsledku svých subjektivních přesvědčení a pojetí výuky.

\section{Metodologie}

\section{Kontext výžumnébo šetreni}

Data, která zpracováváme $\mathrm{v}$ této studii, byla pořízena na podzim 2020 na zakázku Centra informačních technologií (CIT) Filozofické fakulty Masarykovy univerzity (FF MU). Toto centrum si dlouhodobě klade za cíl podporovat učitele FF MU ve využívání digitálních technologií pro potřeby e-learningu, poskytuje jim v tomto směru vzdělávací a poradenské služby. Po přechodu na distanční formu výuky na jaře 2020 se e-learning stal klíčovým nástrojem výuky a CIT sehrálo významnou úlohu $\mathrm{v}$ adaptaci učitelů FF MU na pandemickou situaci.

Po skončení jarního semestru chtěli členové CIT získat reflektivní zprávu o tom, jak vlastně výuka v jarním semestru probíhala. Cílem bylo zmapovat, jak učitelé FF MU přistupovali k zapojení digitálních technologií do své výuky v souvislosti s nuceným přechodem na distanční formu výuky v průběhu jarního semestru 2020. Jako metoda sběru dat byly zvoleny hloubkové polostrukturované rozhovory s učiteli např́íc různými katedrami FF MU. Z pořízených dat byla sepsána výzkumná zpráva pro potřeby CIT, v níž byl kladen důraz především na odhalení mechanismů, jimiž učitelé zvládali neobvyklou situaci, detekování forem účinné podpory a identifikace dalších možností, jak saturovat rozvojové potřeby učitelů v oblasti práce s technologiemi. 
Pořízený datový materiál je však natolik bohatý, že umožňuje další, méně utilitární analýzy. V průběhu zpracovávání zprávy pro CIT jsme si povšimly toho, že učitelé velmi rozvitě vyjadřují své subjektivní učitelské teorie a přesvědčení o tom, co tvoří kvalitní vysokoškolskou výuku. Zárodečná analýza naznačovala, že subjektivní pojetí výuky se u učitelů ve vzorku silně propisovalo do toho, jak přistoupili k realizaci distanční výuky za pomoci digitálních technologií. Proto jsme se rozhodly toto vynořivší se téma zpracovat detailně a výstupem je tato studie.

\section{Vzorek}

Na konci jarního semestru 2020, který byl z větší části ve znamení nouzové distanční výuky, byl prostřednictvím CIT rozeslán vedoucím jednotlivých kateder na FF MU dotazník vztahující se k jejich záměru i v následujícím období realizovat distanční výuku za pomoci digitálních technologií. V daném okamžiku se ještě počítalo s tím, že restriktivní opatření nebudou pokračovat nebo budou velmi mírná a že nebude nutné výuku v podzimním semestru realizovat distančně. Odpovědi z dotazníku tendovaly spíše k preferenci prezenční výuky, případně k nějaké formě kombinace obou možností (blended learning).

Respondenti, kteří odpověděli na výše zmíněný dotazník, byli následně osloveni se žádostí o rozhovor. Převážně šlo o vedoucí jednotlivých pracovišt' na fakultě. S těmito respondenty jsme pořizovaly prvotní rozhovory, přičemž konstrukce vzorku pokračovala metodou sněhové koule (Švaříček \& Šed’ová, 2007), kdy respondenti postupně dodávali další tipy na vyučující, kteří měli zájem se k výuce v jarním semestru 2020 vyjádřit. Společně se zástupci CIT jsme vyhodnotili, že pro účely výzkumu bude vhodné zahrnout do výzkumu všechna pracoviště na fakultě a tím získat horizontálně komplexní zpětnou vazbu.

Záměrně jsme proto dále oslovovaly vyučující z pracovišt', která do té do-by nebyla do sběru zahrnuta. Tímto způsobem se nám podařilo pokrýt téměř všechna výuková pracoviště na FF MU, kromě tří (Katedra informačních studií a knihovnictví, Seminář estetiky a Ústav pomocných věd historických a archivnictví), která na naši žádost o spolupráci nereagovala. Celkem jsme zrealizovaly 34 rozhovorů v průměrné délce 90 minut. Zastoupení učitelů $\mathrm{z}$ jednotlivých ústavů a kateder bylo následující: $2 \times$ Centrum asijských studií, $2 \times$ Historický ústav, $2 \times$ Katedra anglistiky a amerikanistiky, $1 \times \mathrm{Ka}-$ tedra divadelních studií, $1 \times$ Katedra filozofie, 1× Psychologický ústav, $2 \times$ Seminář dějin umění, 1× Ústav archeologie a muzeologie, $2 \times$ Ústav české literatury, 1× Ústav českého jazyka, 1× Ústav evropské etnologie, 1× Ústav filmu a audiovizuální kultury, $2 \times$ Ústav germanistiky, nordistiky a nederlandistiky, $2 \times$ Ústav hudební vědy, 1× Ústav jazykovědy a baltistiky, 1× Ústav klasických studií, 1× Ústav pedagogických věd, 1× Ústav religionistiky, 
4× Ústav románských jazyků a literatur, 4× Ústav slavistiky, 1× Centrum jazykového vzdělávání. Respondenty jsme ujistily o zachování důvěrnosti získaných informací a veškeré informace jsme anonymizovaly, respondentům byla přidělena fiktivní jména. Z respondentů zahrnutých do vzorku jich 13 vykonávalo na svých pracovištích řídící funkci (jako vedoucí či zástupci vedoucího), 21 respondentů se rekrutovalo z řadových učitelů.

Vzorkování jsme ukončily na počtu 34 rozhovorů, a to ve chvíli, kdy jsme každé pracoviště (s výjimkou tří uvedených výše) měly ve výzkumném souboru zastoupeno alespoň jedním rozhovorem a zároveň data začala vykazovat zjevné známky teoretické saturace, to znamená, že přestalo docházet k vynořování nových témat a informací (Strauss \& Corbinová, 1999).

\section{Sbèr dat}

Vzhledem k tomu, že naším cílem bylo zmapovat myšlení a jednání aktérů v nové a dosud nepopsané sociální situaci, byla zvolena kvalitativní výzkumná metodologie (viz Švaříček \& Šed’ová et al., 2007). Pro sběr dat byl využit hloubkový polostrukturovaný rozhovor. Tazatelkami byly dvě autorky této studie: Barbora Nekardová a Katarína Rozvadská.

Předem připravené měkké schéma rozhovoru obsahovalo celkem 30 otázek, které byly tematicky rozděleny na pět oblastí. První oblast se týkala toho, jak učitelé využívali digitální technologie ve své výuce před vypuknutím pandemie covid-19. Druhá a třetí oblast se věnovala vnímání změn v jarním semestru 2020 a zapojení digitálních technologií do výuky v tomto období. Čtvrtá oblast se zaměřovala na problémy a výzvy spojené se zapojením technologií do výuky a pátá oblast rozhovor uzavírala otázkami zaměřenými na možnosti dalšího využívání technologií ve výuce učitelů po získaných zkušenostech během pandemie $\mathrm{v}$ jarním semestru.

Rozhovory byly pořizovány v období srpna až prosince 2020. Tento časový rámec vedl k určitým proměnám ve výpovědích respondentů. Respondenti interviewovaní před začátkem podzimního semestru 2020 ( $n=20$ ) označovali distanční výuku za jimi nepreferovanou variantu, přičemž neočekávali, že by tento typ výuky měl nadále pokračovat, a proto se na tuto variantu nijak záměrně nepřipravovali. Oficiální informaci o tom, že podzimní semestr 2020 bude znovu distanční, dostali zaměstnanci FF MU 21. 9. 2020. Respondenti interviewovaní po tomto datu $(n=14)$ již akceptovali přechod na distanční výuku jako dlouhodobou záležitost a uvažovali nad tím, jak výuku v podzimním semestru pojmou, přičemž odkazovali ke zkušenostem z jarního semestru. Ve výsledku se tak pořízené rozhovory vztahují k výuce v jarním semestru 2020, zčásti však rovněž pokrývají koncepci a realizaci výuky v podzimním semestru 2020 a vyhlídky na semestry následující.

Rozhovory byly realizovány tváří v tvář (27 rozhovorů) nebo online prostřednictvím MS Teams (7 rozhovorů). Průměrná délka rozhovoru byla 
90 minut. Respondenti byli informováni o tom, že cílem výzkumu je vytvoření analytické zprávy pro CIT a př́ípadné vytěžení dat do odborných studií na téma vysokoškolské výuky v pandemii (prvním výstupem je tento článek). Respondenty jsme ujistily o zachování důvěrnosti získaných informací a slíbily jsme jim, že veškerá data budou anonymizována (respondenti nejen získali přezdívky, ale anonymizovaly jsme všechna další jména a konkrétní informace, které by mohly vést $\mathrm{k}$ odhalení identity jednotlivých aktérů). Rozhovory byly nahrány na diktafon a posléze přepsány dle jednotného vzoru do podoby textu. Výsledný datový korpus tvořilo více než 350 stran textu.

Doplňkově jsme použily další metodu sběru dat, a to dotazníkovou anketu distribuovanou respondentům ex post $\mathrm{v}$ jistém časovém odstupu od rozhovorů. Dotazník jsme konstruovaly až v průběhu iniciální analýzy dat $z$ rozhovorů a jeho cílem bylo ověrit, zda se respondenti chápou více jako výzkumníci či učitelé. Dotazník obsahoval pět uzavřených otázek, vyplnilo jej celkem 30 respondentů.

\section{Výzkeumné otázky a analytický postup}

Jak jsme uvedly výše, pořízené rozhovory představují velmi bohatý datový zdroj. V této studii se nevěnujeme komplexní analýze nasbíraného materiálu, nýbrž se soustředíme na následující výzkumné otázky:

1) Jak učitelé FF MU chápou koncept kvality v distanční výuce za použití digitálních technologií?

2) Jak se do využívání digitálních technologií v distanční výuce propisuje subjektivní přesvědčení učitelů a jejich pojetí výuky?

Vycházíme přitom z prredpokladu, že právě subjektivní pojetí výuky a subjektivně definovaná př́esvědčení o tom, jaké charakteristiky má kvalitní vysokoškolská výuka, mají potenciál přispět k vysvětlení značné heterogenity v tom, jak různí učitelé přistoupili k zajištění výuky v pandemii.

Data jsme zpracovávaly v softwaru ATLAS.ti (verze 8.0) pomocí několika kódovacích postupů. Nejprve všechny tři autorky metodou induktivního otevřeného kódování zakódovaly každá několik rozhovorů. Následně jsme v týmu porovnaly vzniklé kódy a diskutovaly různé pohledy na data. Následně jsme aplikovaly kategorizaci složek různých pojetí dobré vysokoškolské výuky vytvořenou Šed’ovou et al. (2016). V datovém materiálu jsme dále vyhledávaly výpovědi, které odpovídaly jednotlivým složkám, a označovaly je př́slušnými deduktivními kódy (předat znalosti, kultivovat myšlení, prakticky aplikovat, zaujmout, interagovat se studenty, vložit energii, nastartovat studenty). Zároveň jsme ale i v této fázi udržovaly úroveň induktivního kódování a všechny pasáže jsme zároveň označovaly jemnějšími kódy volenými ad hoc v procesu otevřeného kódování (např. interagovat se studenty: poskytnout zpètnou vaz̧bu k. chybám). 
V následující fázi jsme prováděly komparativní analýzu např́í jednotlivými př́ípady. Porovnáváním výpovědí různých respondentů jsme dospěly k vytvoření dvou polárně odlišných ideálních typů (Weber, 2009), které jsme nazvaly funkecionalisté a autentisté. Dále jsme pracovaly na extrakci klíčových aspektů, v nichž se tyto dvě skupiny učitelů odlišují. Poté jsme znovu analyzovaly každý jednotlivý rozhovor a určovaly, zda daný učitel reprezentuje spíše funkcionalistický či autentistický pól. Přitom jsme revidovaly konstrukci obou typů tak, aby dobře odpovídala všem př́padům v našem vzorku. Využívaly jsme kódy vztažené $\mathrm{k}$ pojetí dobré výuky vytvořené $\mathrm{v}$ předchozí fázi, avšak sloučily jsme je do dvou velkých klastrů, které dobře reprezentovaly to, co se v odpovědích respondentů vyjevovalo jako dominantní: důraz na obsahy (predat znalosti, kultivovat myšlení, prakticky aplikovat) a důraz na interakce (zaujmout, interagovat se studenty, vložit energii, nastartovat studenty).

Výsledková část této studie je organizována tak, že nejprve obecně představíme oba identifikované typy učitelů a následně podrobněji rozebereme, jak tito učitelé přemýšlejí o kvalitě své výuky v obou hlavních složkách, jimiž jsou obsahy a interakce.

\section{Limity studie}

Tato studie má několik limitů, které je třeba vzít potaz při čtení výsledků. Prvním limitem je skutečnost, že učitelé byli do výzkumu zapojováni na základě jejich vlastního zájmu a chuti o tématu hovořit. Domníváme se, že tímto způsobem došlo k tomu, že jsou ve vzorku reprezentováni především učitelé, kteří sami sebe vnímají jako dobré učitele a mají za to, že se k výuce $\mathrm{v}$ pandemii postavili svědomitým způsobem.

Druhým významným limitem je skutečnost, že data zachycují výhradně vlastní pohled učitelů na jejich výuku v době pandemie a nemáme observační data z výuky samotné. Jde o důsledek skutečnosti, že jsme chtěly získat informace o situaci, která $\mathrm{v}$ době plánování sběru dat již proběhla (výuka v jarním semestru 2020) a bylo třeba o ní referovat retrospektivně. Zároveň platí, že ochota učitelů poskytnout rozhovor o výuce je nepochybně vyšší než ochota učitelů být sledováni při výuce. $Z$ tohoto důvodu jsou výzkumy zahrnující přímé pozorování vysokoškolské výuky poměrně vzácné, což může souviset s obavami akademiků ze „zviditelnění“ jejich výukových postupů (Marek, 2009; McQuiggan, 2007). Vzhledem k dlouhodobosti pandemických opatření zůstává výzkum založený na přímém či zprostředkovaném pozorování vysokoškolské online výuky výzvou, která by měla být naplněna. 


\section{Výsledky}

\section{Dvojíprístup k vysokoškolské výuce}

Výpovědi učitelů $\mathrm{v}$ našem vzorku se z hlediska toho, jak hovoří o výuce, rozepínají mezi dvěma póly. První pól, který dále označujeme jako funkcionalistický, zdůrazňuje racionální a cílevědomý prrístup k výuce s cílem naplnit plánované didaktické funkce. Učitelé hovoří o tom, že analyzují vzdělávací potřeby studentů, plánují svůj postup na úroveň dílčích kroků a snaží se kontrolovat jeho efekty. Na druhém pólu, který dále označujeme jako autentistický, je výuka vnímána jako do jisté míry ezoterická záležitost, která je založena na autentickém setkávání a společném přemýšlení a jako taková je jen obtížně plánovatelná a kontrolovatelná.

Výše jsme uvedly, že oba identifikované typy chápeme po metodologické stránce jako ideální (Weber, 2009). Někteř́ z našich participantů poměrně jednoznačně inklinují bud' k funkcionalistickému, nebo k autentistickému pólu. U jiných je patrná nižší míra vyhraněnosti, přesto mají $\mathrm{k}$ jednomu z př́istupu blíže. Funkcionalistický přístup je ve vzorku zastoupen hojněji, kloní se k němu 20 učitelů. Učitelů s autentistickou inklinací je 14.

\section{Funkcionalisté}

Tito učitelé vycházejí z toho, že si stanoví cíl a monitorují jeho dosahování. Př́kladem takového př́istupu je Libuše:

Pro mé je duiležité, aby ten prèedmèt zuládli, aby se naučili, aby si z. toho nèco odnesli, tak proto je tam ta e-learningová podpora tak propracovaná. [...] Kdy̌̌jjsem se divala, tak studenti - jako ta úspěšnost a neúspěšnost byla srovnatelná s tím, jako když to bylo jako prezenčni výnka, takžce pár studentu to se tréba nedostavilo, nebo neudèlalo, nebo ₹. néjakého dìvodu už to udèlat nechtèli, nebo nèco podobnébo, ale to procento bylo velmi malé.

V této výpovědi vidíme, že je „zvládnutí“ předmětu studenty stanovené jako cílová meta a „e-learningová podpora“ jako nástroj k jejímu dosažení. Dále citace ukazuje, že si Libuše klade otázku po efektivitě svých postupů a hledá možné zdroje dat $\mathrm{k}$ jejímu zodpovězení, $\mathrm{v}$ tomto př́padě jde o podíl studentů, kteří kurz dokončili v době pandemie a jeho srovnání s předpandemickými čísly.

Funkcionalisté sebe sama vidí jako někoho, kdo něco dobře ovládá a jehož misí je zprostředkovat to studentům. Takto se charakterizuje např́íklad František:

Já se sám vidím jako praktik, takě̌e kdyžjjem získal úvazek na fakultè, tak jsem byl hroznè štastný, že mữ̌̀ v praxi lidem pomáhat, aby ty jejich výstupy byly prostě dobrý... Takě̌e pro mèje asi dưležitý jako vidèt, že tím nějakým zppisobem pomáhám nebo že pomáhám jako svètu... V̌̌dycky mám dobrý pocit z. toho, když jako tušim, že se studenti tréba nèco naučili. 
V této výpovědi je zjevný důraz na předávání znalostí a dovedností od učitele ke studentům, které má charakter pomoci studentům (slovy Sáry „obohacení studentư “) a předpokládá se praktický dopad takto předaného vědění. Zároveň vidíme silné pozitivní emoce a osobní uspokojení, které učiteli jeho vzdělávací činnost přináší.

Funkcionalistům je vlastní starost o kvalitu výuky, která je součástí jejich pedagogické cti. Václava říká: „Já bych si to osobně asi špatně srovnávala se svým svědomím, že jsem jako by neodučila to, co jsem měla." Pedagogická čest je vede $\mathrm{k}$ tomu, že odmítají minimalistická řešení a na učitele, kteří k nim tendují, nahlížejí negativně. Slovy Petra: „Co jsem nechtěl dělat, bylo to, že bych jenom jako řekl tady máte studijní literaturu, naučte se to a prostě uvidíme se jako u zkoušky, jo? Jak to někteří kolegové dělali.“ Vidíme, že Petr odmítá možnost odkázat studenty na samostudium, domnívá se totiž, že by tím nenaplnil svoji úlohu učitele. Tento osobní rys vedl funkcionalisty hned $\mathrm{v}$ počátcích distanční výuky $\mathrm{k}$ tomu, aby hledali různé nástroje, jak kvalitně nahradit výukové činnosti, které předtím probíhaly tváří v tvár. Vystihuje to např́lklad výpověd’ Anny:

Takeže já néco prednesu a potom vąnesu dotazy, a to i v té prezenčni výuce, protože ono, uprímnè réréno, hodinu a puil nèkeoho poslouchat... at' mluvi sebezajímavěji, tak ta pozornost upadá, a vždycky se oživí, když studentiom zadáte nějaký úkol, tak. právě to byl potom také divvod, proč jsem potom prèsla na Zoom, protože ten Zoom umožnuje rozdèleni studentů do skupin, které pracuji v těch samostatných pokojich, rooms, takè̌e si je rozdèlite, zadáte studentuim rịnou práci nebo rüzným skupinám rüznou práci, potom se spojite a vlastně simulujete nèjaké aktivity, keteré by byly mo:̌né prì té prezenčni výuce.

Anna nejprve nahradila prezenční přednášku online synchronní lekcí v aplikaci MS Teams. Dále přemýšlela nad tím, jak substituovat kreativní studentské aktivity, které do svých lekcí zařazovala. Za tímto účelem zvolila formát skupinové práce, protože $\mathrm{v}$ tomto uspořádání dostanou studenti větší prostor pro své promluvy a aktivní participaci, což vede $\mathrm{k}$ „oživení pozornosti““. Byla ochotná opustit aplikaci MS Teams, se kterou již měla zkušenost, a přjejit k aplikaci Zoom, jakmile usoudila, že zahrnuje nástroje lépe vyhovující jejím didaktickým záměrům. Z citace je zjevné, že funkcionalisté analyzují didaktické funkce bežných výukových postupů a hledají k nim distanční ekvivalenty. V jejich pojetí je kvalitní vysokoškolská výuka především o vytváření podpory pro studenty s cílem usnadnit jim osvojování nových vědomostí a dovedností.

Pandemická situace v kombinaci s pedagogickou ctí vedla funkcionalisty $\mathrm{k}$ akceleraci rozvoje jejich technologicko-pedagogických dovedností. Tito učitelé byli ochotni věnovat mnoho energie tomu, aby si osvojili adekvátní nástroje. Petr to komentuje: 
Musel jsem vlastně vǐechno, co jsem mél prïpravený, préklopit do nèjaký jiný formy. Takeže to byla docela dost práce, bylo dost práce is tèma videama, já jsem si to dèlal celý sám. Já vím, že jako jsou i jiné možnosti, ale já jsem se to chtél jako naučit sám dèlat, co:̌̃jako, jo, ty videa, jeden den jsem je natáčel, a pak mi zabralo tréba dva dny je sestríhat, já jsem do toho ješté pridával nèjaké efektty. Abych tam jenom tak. nemluvil já, jakeo blava, takejsem tam jako dával nèjaký obrázky tam, titulky tam prolitávaji a takový véci. Takeže tak. Na drubou stranu jsem se to naučil, jako dělat stim, s tèma programama.

Petr na jednu stranu konstatuje, že transformace výuky do distanční podoby byla velmi pracná, zároveň však šel v technologických postupech nad úroveň nutného. Ochota vynaložit takové množství času a energie do př́pravy na distanční výuku poukazuje na to, že „osobní výtěžek“ v podobě osvojení nových doved ností byl tímto učitelem vnímán jako velmi silný.

Ozvuky řad témat nastíněných výše lze nalézt ve výpovědi Virginie:

Kvalitni výnka s využitím digitálnich technologii... to si myslim, že je to o té prípravě. Že když si prippravím nèjaké to blasováni, nèjaké ty motivačni úkoly a prippravím si je tak, že jednak to bude bavit mé i ty studenty, a blavně asi ty studenty, pak.je to kvalitni výuka ... anebo jsou ty technologie kvalitně využité v té výuce. Pokud to ty studenty nebude bavit, ale já jsem do toho investovala spoustu hodin a vidim, že je to nebavi, že to nevyužili, že odcházejí nebo ty reakce jsou takové jako rozporuplné, tak. zase to je výzva, aby to člověk dělal zase nèjak. jinake, jo... našel si nèjaké nové nástroje, jiné platformy a nebo se prostě poradil s někým jiným a zase se to pokoušel nèjak zlepsìt.

Vidíme podobné prvky jako v předchozích výpovědích. Sára se neomezuje na četbu nebo nahraný výklad, využívá další nástroje (hlasování, motivační úkoly) k naplnění svého didaktického plánu. Podobně jako Petr konstatuje masivní časovou investici, ale považuje to za nutnou daň kvalitní výuky s využitím technologií. Ani takto důkladný vklad do př́ípravy Sára nepovažuje za garanci kvality a efektivity výuky, monitoruje proto reakce studentů a jejich výsledky. Nepřijetí či nevyužití na straně studentů potom nevnímá jako selhání, nýbrž jako impulz pro další rozvoj svých technologicko-pedagogických dovedností.

\section{Autentisté}

Jestliže pro funkcionalisty je výuka něco, co je potřeba dobře naplánovat a monitorovat, autentisté mají za to, že jde o magii (slovy Borise), show (slovy Filipa), dialektiku (slovy Lea). Jde o něco, co se děje živelně a je to syceno myšlenkovými pochody všech zúčastněných, které se vyjevují ve vzájemné komunikaci, interagují spolu a tvoří amalgám nového poznání. Autentisté nezavrhují funkcionální př́stup, ale osobně se $\mathrm{k}$ němu nehlásí. Boris říká: 
Myslim si, že je dobrý mit nadesignovaný dopredu, co chci jako docílit a rüznýma otázkama je ke tomu jako docpat, ale to je treba presnè to, co mé jako moc nebaví, jo, jako:̌̀e prostè spís nèjak jako vřdycky čekám, co z té hodiny jako vyplyne a spišs máme jako kedyby ty oblasti, o kterých bych chtèl mluvit, ale nemám úplnè to, k čemu se treba nutnè musim dostat.

V Borisově výpovědi vidíme určitý pedagogický hédonismus (nedělá, co jej nebaví), který autentisty odlišuje od funkcionalistů, kteří se více řídí svou pedagogickou ctí (dělají, co je správné). Boris si je vědom možnosti výukový postup naplánovat do posloupných kroků směřujících $\mathrm{k}$ předem vytčenému cíli. Preferuje však podřídit se spontánnímu vývoji lekce, který je podle něj předem nepredikovatelný. Jeho výukový plán se omezuje na tematické oblasti, které jsou podle všeho vymezeny spíše volně. V autentistickém pojetí nejsou studenti čistě v receptivní roli, nýbrž se spolupodílejí na vytváření znalostí a dovedností přímo ve výukovém procesu.

Autentisté velmi zpochybřují dopad samostudia z předem připravených materiálů. Slovy Václava:

Je to jako kdybyste se chtéli učit ciži jazyk a méli jenom učebnici a neméli ke tomu žádného učitele nebo ani dokonce byste neméli s kým o tom mluvit, takže byste byli odkázáni jenom na tu učebnici, a i kdybyste se tu učebnici naucili nazpamèt', take poŕád ten jazyke prostě nebudete znát.

$\mathrm{V}$ tomto pojetí je k vytváření vědění nutná interakce různých aktérů. Předpokládá se aktivita studentů samotných, avšak role učitele je viděna jako zásadní. Johan o e-learningu říká:

To, čho se bojim, je to, že ti studenti jako naprosto żtrati néjakou orientaci v tom tématu. Vètšina lidí má prostě pocit, že literatura znamená naučit se néjaký data anebo prostě nechat se bavit, jo, nebo néco takovýho, ale prostě objevovat v textu je nèco, co jako moc lidí se nenauř́... A to je tréba nèco, co já bych jim v prezenčni výuce mobl dát a co mi pres ten počítač nejde.

Vidíme rozdíl oproti funkcionalistům, kteří výuku rozloží na funkční komponenty a hledají k nim online ekvivalenty. Autentisté mají za to, že dobrá výuka stojí na osobních kvalitách učitele, a to včetně těch, které se uplatňují právě jen při osobním kontaktu. Podle Filipa absence osobního kontaktu zpo̊sobuje ,dehumanizaci výuky“.

Koncept vysokoškolského učitele je pro autentisty silně spojen s jeho schopností generovat poznání. Jak říká Leo:

Dobrý učitel musí být dobrý badatel. Když vy nedèláte špičkovej výzkum, tak nemáte bloubku, abyste mobla dloubodobè prèdnášet kvalitně na univerzitě̀. Č́m hlouběji jdu jako v tom intelek.tuálnim badatelském svètè, o to víc mám co prédávat. Poznání, keterý tvorim, takeže já jsem jako aktér toho poznáni, ne jenom receptor, prostě neshrnuju stránky Wikipedie pro moje studenty, ale rúkám jim nèco, co ještě nebylo napsáno. 
Zatímco funkcionalisté se vidí jako ti, kteří dobře ovládají určité vědomosti a dovednosti a dokážou zajistit jejich transmisi ke studentům, autentisté kladou důraz na tvorbu. Tím dochází ke ztotožnění učitele a badatele, přičemž excelentní učitel by měl být $\mathrm{v}$ tomto pojetí špičkovým badatelem, vytvářet originální hluboké znalosti.

Výše uvedené rysy autentistů předjímají jejich postoj $\mathrm{k}$ online výuce. Vzhledem k tomu, že neumožňuje intenzivní spontánní interakci mezi tvořivým učitelem a jeho aktivními studenty, je nahlížena jako řešení z nouze, které je však nutně deficitní. To ilustruje výpověd’ Hany:

Myslim, že ta osobni interakce, že je to nèco exkluzivníbo a mèlo by to být nèco luxusního pro ty studenty. Vìimnète si, že u takových tèch velkých online kurziu, že tam jde v podstatě o marketing a jako demokratizaci toho poznání, která je fajn, ale to nejvy̌̌šri vèdèni se prenási mezi malými skeupinami lidí. A myslím si, že je to v osobnim kontaktu, že vidite, jak ten člověk pracuje jako vỹzkumnik.

Vidíme, že online výuka je $\mathrm{v}$ citaci ztotožňována s velkými kurzy směřujícími k demokratizaci poznání, to znamená k jeho šíření mezi množství lidí. Naopak „nejvyšší vědění se komunikuje v malých společenstvích, v nichž učitelé vytěžují svou výzkumnou práci v osobním kontaktu se studenty. Od tohoto názoru již není daleko ke konstatování, že plnohodnotná online výuka není možná. Tadeáš se o jednom ze svých kurzů vyjádřil takto: „Koncepce toho předmětu vůbec neumožnila přejít do distanční výuky. A říkám, nebráním se tomu předmět pojmout jinak, ale tak, jak byl postavený, tak prostě ta distanční výuka byla jenom náhrada." $V$ tomto ohledu se opět autentisté odlišují od funkcionalistů, kteří při přechodu na distanční výuku okamžitě začali experimentovat s různými nástroji s cílem efektivně substituovat činnosti, které předtím probíhaly tváří v tvár. Je příznačné, že zatímco funkcionalisté $\mathrm{v}$ rozhovorech jmenovali řadu nástrojů a aplikací, které využívají, v rozhovorech s autentisty se takové zmínky objevovaly jen sporadicky. V kontrastu s činorodostí funkcionalistů autentisté vcelku otevřeně přiznávají svou bezradnost $\mathrm{v}$ počátcích pandemie, kdy nedokázali rychle přepnout do plnohodnotného online režimu. Václav to glosoval takto: „Byl jsem z toho hodně smutný a dost mě to trápí teda, jak to dopadlo v tom jarním semestru.“ Johan na otázku, co je podle něj kvalitní online výuka odpovídá:

Pokud by to mélo být fakt kvalitni, tak to musi být v malých skupinách a musi to prékonat hodnè tèch tě̌̌ kostí, keterýp pri normálnim kontaktu nejsou a musi tam být... ale do toho jsem zatim jako nepronikl... vlastne protože trošku nechci... musi tam být asi jako spousta nèjakých rĩzných technických vychytávek, který jako zatím neznám... 
Znovu vidíme důraz na malou velikost učební skupiny, která je pro autentisty typická. Johan dále konstatuje, že existuje mnoho nástrojů, které umožňují vést kvalitní online výuku. Oproti kolegům funkcionalistům však s těmito nástroji neexperimentuje důsledně a aktivně, pandemická situace se nestala důrazným stimulem pro jeho technologicko-pedagogický rozvoj. Nelze přitom říci, že by za malou akčností autentistů při implementaci technologií stála jejich nízká uživatelská zběhlost. Naopak, někteří z nich se v rozhovorech deklarovali př́ímo jako digital natives (např. Boris, Gabriel, Tadeáš).

Rezervovanost vůči technologiím, která je pro autentisty typická, vede ke skepsi ohledně budoucnosti. Fakt, že pandemická situace akcelerovala elektronizaci výuky, vnímají negativně a je zdrojem jejich obav. Jak říká Václav: „Trošku se bojím toho okouzlení, které se dostavilo. Trošku se bojím nápadů, že online ted’ bude prostě celá výuka už navždy.“ Velmi důrazně pak tuto myšlenku formuluje Leo, když odmítá využití online výukových forem, které si učitelé nově osvojili, do postpandemické doby:

Univerzita jako taková můře prestat existovat, když budeme tvrdit, že jde nabradit takovým jako polotovarem. Já si myslím, že je to extrémně pesimistická vèc a ẓ̌e jestli se jako opravdu z tohoble tragickýbo obdobi chceme jako udèlat opravdovou tragédii, tak to je jako vlastnè likvidace vaděláni terciárního skrze tu online výnku.

Univerzitní prostředí je pro autentisty nositelem humanistických hodnot, které nejsou přenositelné do online prostředí. Online výuka je označována jako „polotovar“ a představuje pro kvalitu vysokoškolského vzdělávání potenciální „likvidačni““ nástroj.

\section{Hledání kvality výuky}

Jak jsme uvedly v teoretické části této studie, při uvažování o kvalitě výuky se obvykle berou $\mathrm{v}$ potaz dvě základní kategorie: vzdělávací obsahy a interakce se studenty. Tyto dvě složky se přirozeně objevily v našem datovém materiálu. Učitelé přemýšleli, jak v online výuce poskytnout studentům př́stup ke kvalitním vzdělávacím obsahům a zajistit jejich osvojení. Zvažovali také, jakým způsobem bez možnosti osobního kontaktu komunikovat a interagovat se studenty. Do toho, jak učitelé pracovali s oběma těmito kategoriemi, se přitom zřetelně promítalo, zda inklinují spíše k funkcionalistickému, či autentistickému pólu.

Nakládáni se vadèlávacimi obsaby: je e-kopie výnky možná?

$\mathrm{V}$ rozhovorech se participující učitelé vyjadřovali $\mathrm{k}$ tomu, do jaké míry je možné vytvořit funkční kopii výuky pomocí elektronických nástrojů - dále pro tento koncept budeme používat termín e-kopie výuky. Zde se jasně uka- 
zoval rozdíl mezi funkcionalisty a autentisty. Zatímco podle funkcionalistů je e-kopie proveditelná, a může dokonce předčit to, co nabízí prezenční výuka, podle autentistů je e-kopie nemožná a snahy o ni mohou mít paradoxní účinky. Tato polarita v pohledu na elektronizaci výuky vychází z odlišného sebepojetí učitelů, které jsme nastínily v předchozí kapitole. Funkcionalisté se vidí jako ti, kteří zprostředkovávají vědění. Online prostředí je pro ně potom repozitářem obsahů, které $\mathrm{v}$ něm mohou systematicky a přehledně uspořádat a studenti k nim mají snadný př́stup. Oproti tomu autentisté se vnímají jako ti, kteří vědění tvoří, a to $\mathrm{v}$ procesu symbiotické interakce se studenty. V samotném ukládání obsahů do elektronického prostředí nevidí podstatu své učitelské práce.

Funkcionalistickou pozici vyjadřuje Virginie:

Já bych úplnè nedèlala zas takový rozdil mezi kvalitni online výukou a kvalitní

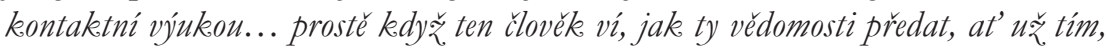

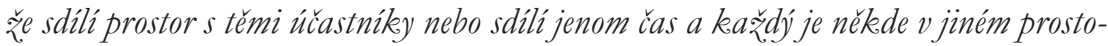
ru ... tak ǔ̌je asi jedno, jestli je to digitálně, nebo kontaktné.

$\mathrm{V}$ úryvku vidíme důvěru funkcionalistů $\mathrm{v}$ substituovatelnost prezenční výuky, pokud má učitel dostatečnou pedagogickou expertízu („ví jak vědomosti předat").

V podobnému duchu se nese řeč Sáry, která popisuje, jak zajišt'ovala distanční výuku.

Já jsem každý týden celou tu výnku natáčela, natáčela jsem ji teda v prostredí na fakultè a vlastnè simulovala jsem tím úplnè klasickou prednášku. To żnamená, bylo to se visim, bylo to s prezentací, s ukázkama, samozrérjmè nebylo to s diskusí, ale

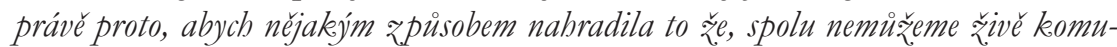
nikovat, tak mèli dalši sérii takových menšich úkolu z týdne na týden, které se vž̀dy vázaly k té konkrétni prednásce. Takeže to, co se vlastnè v prezenční výuce odehrávalo $v$ prednášce, že jsem tréba prerušila výklad a udèlali jsme si takový brainstorming, kede jsem je jako nutila, aby se nad tim zamysleli, tak to jsem prevedla do úkolu vlastnè pisemného typu.

Tato výpověd’ dobře ilustruje logiku vytváření e-kopie. Různé výukové aktivity jsou „simulovány“ či „,nahrazovány“, pro každou lze nalézt elektronický ekvivalent, byt’ na první pohled poněkud vzdálený. Např́ílad živá diskuse je nahrazena písemnými úkoly. Vyučující zde netvrdí, že jde o totéž, převodní mechanismus tvoří shoda ve funkci (,aby se nad tím zamysleli“).

Funkcionalističtí učitelé oceňují možnost využití širšího množství zdrojů než $\mathrm{v}$ př́padě klasické přednášky. E-kopii je možné doplnit odkazy do virtuálního prostoru, které mohou značně rozšíŕit záběr. Stejně tak je možné $\mathrm{v}$ online výuce přizvat experta na určitou problematiku, čímž se opět výuka obsahově obohacuje. Libor to popisuje takto: 
Na jednu hodinu, kede jsme brali autora XXX, jsem pozval pana doktora XXX z. Akademie vèd, který právě se tím autorem intenzivně zabývá. Což vlastnè by se nám možná normálně nepodarilo, protože on by sem musel prïjet a bylo by to složitějši, zatímco takble já jsem ho požádal a on se prostě k nám prípojil, jo, a studenti byli nadšení. To bylo super.

Vedle možnosti rozšíření obsahů funkcionalisté kvitují s povděkem také potenciál elektronického prostředí výuku konzervovat v čase. Sára například nahrávala své přednášky a ty ponechávala studentům $\mathrm{k}$ dispozici po celou dobu trvání kurzu:

Tak si to všichni pochvalovali, protože se k tomu mobli vracet, protože tim, že to je velmi faktografický kurz, tak to, že to méli tedy nabrané, pro né bylo velmi pohodlné, protože i pri prípravě na tu qkoušku se mobli k tém nabrávkám vracet, takę̌e jako technicky to bylo skevelée.

Souhrnně lze říci, že pro funkcionalisty představuje elektronizace vítaný způsob, jak překonávat prostor a čas.

Fenomén času se ve výpovědích těchto učitelů objevoval ještě v dalších variacích - e-kopie způsobuje jakousi jeho elasticitu. Na jedné straně je možné čas věnovaný přednášce zkrátit, jak upozorňuje Patrik:

Uřetrí se čas, jako zjistil jsem, že normálně prednáška trvá hodinu a pưl, tak tam má spoustu tèch prázdných nebo spišs oddychových mist, která když se vlastně odmáznou tim, že se to nahraje, tak je z toho padesát minut.

Zcela opačně využívá elasticitu e-kopie Karel:

To je i treba jedna z výhod, jo, toho online, že ja jim to mưžu pretábnout, že normálné máme vlastnè sto minut na dvouhodinovku klasickou, no ale já jsem holt jsem nèco některé prednášky pretábl třeba o deset patnáct minut, což ale pro ty studenty je ale v distančni výuce víceméné jedno, že, protože oni dostanou materiál a ted'ka jak ten dvoubodinový materiál si rozdèli a mươou to treba poslouchat na etapy, tak si s tím vlastné mi̊žou pracovat, jak chtěji. takě̌e tady vlastnè to pretaženi neni totéž co prétaženi v reálu, jo, kdy já ty studenty vlastnè pripravím o prestávku a sebe koneckoncư taky.

Ačkoli Patrik přednášku zkracuje a Karel prodlužuje, oba případy mají společné, že se v e-kopii učitelé necítí vázáni obvyklým časovým vymezením výuky podle rozvrhu, distanční forma tedy zvyšuje jejich učitelskou autonomii.

Jestliže pro funkcionalisty je e-kopie zcela přijatelnou verzí výuky, autentisté vidí věc jinak. Leo na otázku, jak podle něj vypadá kvalitní online výuka, odpovídá: „Tak kvalitní online výuka existuje, je to věc, kterou dělá výbornej učitel, kterej si s tím dá ohromný množství práce, je naprosto neefektivní a míjí se tím hlavním, což je jakoby ta možnost nějakého dialogu. "Tato významově hutná výpověd’ odhaluje několik podstatných momentů. Leo při- 
pouští, že lze realizovat kvalitní online výuku - zde jako by si uvědomoval existenci funkcionalistů, kteří do výuky vkládají velké úsilí a používají řadu platforem a nástrojů. Zároveň ale jedním dechem dodává, že jde o úsilí neefektivní a mírící zcela mimo hlavní cíl, jimž je dialog mezi učitelem a studenty. Autentisté se domnívají, že to, co tvoří esenci vysokoškolského vzdělávání, je nepřevoditelné do online formy. $Z$ tohoto důvodu např́klad Johan konstatuje: „Já jsem vůbec neuvažoval nad tím, že bych se měl snažit přeložit tu formu toho semináře do online prostředí.“ Jednoduše řečeno, kvalitní online výuka je podle autentistů nemožná mise.

Neochota autentistů vrhnout velké množství energie do tvorby online obsahů a nástrojů je silně propojena s jejich přesvědčením, skutečně hodnotné vzdělávací obsahy nelze fixovat. Slovy Hany:

Já jsem nebyla nikdy nèjaký veliké fanoušek e-learningu z toho divvodu, že vždy, kdy ž jsem se pustila do práce na nèjakém tréba studijním materiálu e-learningovém, já jsem dělala vlastněs IS dvě skripta, který jsou dostupný online, tak mi bylo jasné, kolik. je to práce, odborné i didaktické. A ten obor se samozrrejerev vyviji a prícházi tam nová témata, zuläś' v našem oboru, že tam vlastné neexistuje nèco jako takovej pevnej kánon, keterému by stálo zato vènovat tolike hodin, které vyžaduje vlastnè to prevedeni do toho e-learningu.

Tito učitelé mají ambici sdílet se studenty slovy samotné Hany „nejvyšší vědění", které je v neustálém progresu a tudíž proměnlivé. Zatímco instantní povaha ústního předávání proměnlivost podporuje (učitel např́iklad málokdy zopakuje výklad zcela stejným způsobem), vytvoření učebního materiálu pro e-learning vede ke stabilizaci a umrtvení vývojového potenciálu předávaného vědění.

Nejde jen o to, že do korpusu vědění v dané oblasti přibývají nové a nové poznatky generované jinými vědci. $V$ čase se pochopitelně proměnuje také sám učitel. V autentistickém pojetí, kdy je učitel chápán jako tvůrce vědění, to opět představuje argument proti vytváření, ukládání a šíření výukových materiálů. Jak ř́ká Dušan:

Když napišste néjaký text, tak jako je to je ten text napsaný ke nějakýmu datu. A treba to je zas ta výhoda té prezenčni výnky, že já to mưžn aktualizovat, müžn to prekopávat a samožrejmě vyučuju tady dvanáct let, tak jsem se někeam posunul... Vlastnè to zaváni takovým paradoxem, jakožze nějaká jako technologie vede k zakonzervovanosti.

Jestliže výpověd’ Hany výše implikuje, že e-learning je prýliš namáhavý (odvádí akademika od jiné, více meritorní práce), Dušan už přímo pojmenovává technologie jako hrozbu pro akademický provoz, nebot' vedou k zakonzervování stávajícího vědění a jejich využití má tedy ve vztahu k akademické práci „paradoxni““ efekty. 


\section{Interakce se studenty: jak podporit ǔ́eni a myšleni?}

Všichni učitelé ve vzorku, bez ohledu na svoji funkcionalistickou či autentistickou inklinaci, uváděli nemožnost interagovat se studenty tváří v tvář jako hlavní problém distanční výuky v době pandemie. Liší se však konkrétní důvody, proč je omezení osobní interakce vnímáno jako úhelný kámen online výuky.

Pro funkcionalisty je předání obsahů dominantním cílem, jemuž je interakce podřízena. Tito učitelé považují za nezbytné interagovat se studenty, aby došlo k efektivnímu osvojení vědomostí a dovedností na jejich straně. Libor popisuje učitele $\mathrm{v}$ prezenční výuce jako toho, kdo vysílá informace ke studentům, a studenti je prrijímají. Hlavní potíží je podle něj fakt, že v distanční výuce nelze zajistit a vynutit, aby byli studenti na př́ijmu.

Ten učitel je v uvozovkách povinen jim něco předat a je tam jako nějaká hlásná trouba, to tak jako berem $v$ tom, že najednou je to na tom studentovi, a když chce něco dělat, tak jako jo, ale když nechce, tak ho nikdo nedonutí, protože on si prostě vypne mikrofon, obraz a s tím jako se nedá nic dělat.

Podstatou interakce je tedy podle Libora průchozí kanál od mluvč́iho $\mathrm{k}$ posluchačům. Podobně formuluje své úvahy Igor, který studenty výslovně označuje jako publikum:

Vy mluvite do počitače o svým vlastně powerpointu a to publikum tam chybi prostě. A protože jakoby to povidate vic pro sebe a v té chvili, tak si umim predstavit i to

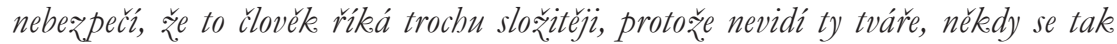
kouknou trochu nediverrivě a vy vite, žce musite zpomalit, jo, tak že toble je problém.

To, co funkcionalistům chybí, je vizuální odezva publika, která je navádí, jak modifikovat svůj projev tak, aby byla zajištěna jeho co nejhladší recepce na straně studentů.

Pokud funkcionalisté tematizují rozhovor nebo diskusi se studenty, zmiňují především jejich přínos pro procesy učení. Jednoduše řečeno, studenti mají hovořit a ptát se, aby si co nejlépe osvojili prezentované obsahy. Petr ř́ká:

Pro mé je nejdưležritějšri, rekenème, to, aby ti studenti se nebáli jakoby mluvit, $i$ kdyby

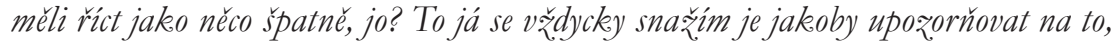
že tady jsou právě od toho, aby se néco naucili, a tím, že jako tu chybu neodhalí, tak.

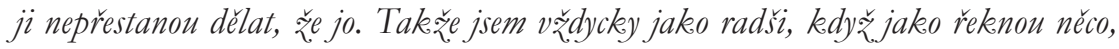
at' to tréba vyargumentujou, $i$ kdy žjom to treba potom vyvrátím, ale jsem rád, kdy ž o tom uvažujou prosté.

$\mathrm{V}$ této výpovědi se rýsuje představa správného vědění, kterým disponuje učitel. Jestliže studenti hovoří, odhalují své vlastní vědomosti či myšlenky, což učiteli umožňuje dát jim zpětnou vazbu ohledně jejich správnosti či adekvátnosti. Interakce učitele se studenty tak umožňuje, aby učitel poskytoval studentům zpětnou vazbu a obecně vzato řídil jejich učení. Libuše dbá na to, 
aby studenti nejen odpovídali na její otázky, ale také otázky sami kladli. Vysvětluje to takto:

V prezenčnim seminári mùže student tu otázku položit hned a jsme tak domluveni,

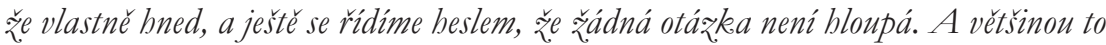
bývá tak, že jeden student položi otázku, ale kedyž se podiváte na ty ostatni, tak.je vidét, ̌̌ze oni ji taky maji, jenom ji nerekeli nablas, takeže vlastně tím, že odpovite jednomu, odpovite $i$ vice studentum. Toto mi v té jako koronavýuce chybělo, $i$ když studenti mèli možnost diskuze v IS, kam jsem se snažila nèjak taky v téch vláknech je aktivizovat, ale bylo vidèt, néketeř̀ to využili, ale ne visichni. Vérim, že kdyby to bylo jako kontaktní výnka, že téch otázek dostanu mnohem víc.

Opět vidíme využití komunikace a interakce pro usnadnění procesu učení. Cílem je na základě studentských otázek detekovat a vysvětlit nejasnosti, a tak facilitovat porozumění prezentované látce.

Funkcionalisté $\mathrm{v}$ rozhovorech príliš nerozebírali obsah a podstatu studentských promluv. Problémem pro ně není, co se komunikuje, ale zda ke komunikaci vůbec dochází. Pro učitele je obtížné komunikační výměnu se studenty v online prostředí rozproudit. Jak ř́́ká David:

Tak ta debata se rozbihá vétšinou tak trochu složitéjc. V tom smyslu, že kdy žprostě oni sedív posluchárně a padne otázka, tak se nikedo neschová. Zatímco za ikonku nebo za prostě krou ̌̌ele s iniciálama se prostě každý schová a nic neř́ká.

Podle funkcionalistů studenti nemluví, protože nejsou koncentrovaní a aktivizovaní, nejsou pod přímou kontrolou učitele, který by je ke koncentraci a aktivizaci přiměl. Slovy Milady:

Mně je úplně jasné, žze si vypnou mikerofon a prostě dèlaji nèco jinébo, takě̌e prostě na nè nevidite do chvile, než je oslovite, a kdy ž to ropakujete napotretí, tak vám dojde, že to tréba nesleduji tak jako aktivně... tak to je samožrejmé jakoby asi... asi nevýhoda. ̌̌e jo. tèch technologií, že préce jenom vy nemáte takový jako dobled a jinak $v$ tèch prednáškách.

Výpovědi Milady i Davida vyjevují koncepci studentů jako spíše neaktivních a nezaujatých, kteří potřebují důrazný nátlak učitele, aby se př́iměli k práci. Právě tento prímý nátlak online výuka neumožňuje, a tím podle funkcionalistů znesnadňuje vyučovací proces. Tento problém funkcionalisté, jak bylo naznačeno výše, řeši činorodým vyhledáváním různých nástrojů (hlasování, testování, odpovědníky, kvízy atd.), které právě k aktivizaci studentů a zajištění kontroly nad jejich studijním chováním směřují.

Také autentisté hovoří o tom, že interakce $\mathrm{v}$ online prostředí je obtížná a nekvalitní. Leo podotýká: „Nejcennější na té výuce je ten jako dialog a ten asi úplně nejde navázat přes tu obrazovku." $\mathrm{Na}$ tomto axiomu se všichni autentisté shodují. Jako důvody, proč tomu tak je, uvádějí ostych studentů před kamerou, technické potíže s připojením nebo nedostatek spontaneity, 
kdy není možné reagovat zcela bezprostředně, je třeba využívat mechanismus hlášení či přispívání do chatu. Boris to komentuje takto:

Pokud opravdu jako se snažím nějakým zpuisobem klást velký dìraz na tu diskuzi, tak to nejde udržet v té stejné míre, protože prostě se jako nepriblási spousta lidí, protože ta technologie je bude odrazovat, jo, anebo ta spontaneita tam nebude, že než to všichni jako reknou, tak prostě zapomenou, co chtèli, a diskuze ve skupinkách nebude, proto ̌̌e to uřjako je asi nad moje technické schopnosti dělat jako v rámci jedné trúdy v Teamsech ješté jako skupinky diskuzní.

Z obou citací je - vedle deziluze ohledně živosti a spontaneity konverzace v online prostředí - zjevná jedna důležitá věc. Autentistům nejde o to, aby studenti odpovídali na jejich dotazy nebo kladli otázky k látce, jíž neporozuměli. Jejich představa o „dialogu“ či „,diskusi“ ve výuce je mnohem komplexnější.

Pro autentisty je komunikace symbiotická s myšlením. Podobně jako funkcionalisté jsou zvyklí v průběhu prezenční výuky klást studentům otázky. Cílem však není zajistit, aby se koncentrovali na výklad, nebo diagnostikovat a napravit jejich nedostatky, nýbrž studenty stimulovat k přemýšlení. Hana říká:

Aby to nebylo tak, že já jim vyprávím, jak to bylo, ale aby oni sami méli ty informace z.pruni ruky a byla tam príležitost pro néjaké vedeni dialogù na to téma, to se mi $i$ zdá jako dilležité vlastnè, predat védomosti, ale i zpuisob treba uvažováni a ukázat jim, že mưžeme mit na jednu véc rưzné názory, jo, třeba si bledám i takové kauzy, kede tréba vaniká nèjaký malý spor těch akademiku na nějaká témata, abych jim ukázala, jak vlastnè dobrodružné to poznáváni na akademické puidě mưre být, $v$ tomble si myslim, že se liši od stredoškolského.

Z promluvy je zjevné, že vedle předání informací jde o navedení na způsob uvažování, v němž jsou pluralita či přímo „spor“ nahlíženy jako legitimní a žádoucí model pro akademické poznávání a cílem učitelky je do tohoto systému myšlenkové produkce studenty socializovat.

Tadeáš se k věci vyjadřuje takto:

To, co potrebuju, je sednout se studenty nad textem a diskutovat, co z toho maji a co je napadlo. Pro mé nejduiležitèjsí je pochopit, co z. toho textu maji oni, abych je navedl na jiné interpretace, nebo prostě abych věděl, kudy vede jejich interpretačni cesta. Tak:že potrebuju živou diskuzi na to. Jinak jako oni se mữ̆ou naucit ty manuály, ty príručky a ty encyklopedický véci prostě brnout na papir nebo ústnè, ale rozbor textu, na to je potréba se ptát poŕád.

Tadeáš odsouvá faktografické vědění („encyklopedický věci“) jako něco snadného, co studenti mohou zvládnout bez sofistikovanější intervence učitele. Meritorní je podle něj „intepretační cesta“, přičemž chce studenty navádět na svůj způsob intepretace, ale také zkoumat jejich intepretační postupy. 
Ty v této citaci nejsou nahlíženy jako nutně méně správné nežli postupy učitele, učitel chce pochopit studentské způsoby čtení a zároveň je pluralizovat. Nejde tedy o to diagnostikovat a napravit chybu, ale ukázat, že je určitou věc možné promýšlet paralelně různými způsoby. Tento důraz na pluralitu je pro autentisty typický stejně jako přesvědčení, že technologie pluralitu myšlení spíše omezují, než že by měly potenciál ji podporovat. Jak říká Filip:

Pluralitu myšleni ten online proces úplně nerozviji. Müj obor je taková jako výrazně interpretačni véda, to znamená hodnè se bavime o tom, jak néjakou událost vyložit

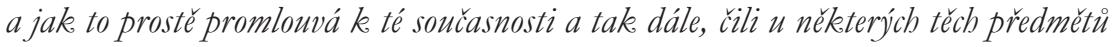
tady tenble ten aspekt prostě v té online výuce byl jako výrazně poškozen. To je taková hodnè živá vèc, ale prostě bez. té debaty to moc nejde a ta online výuka nám tu interpretačni slo そ̌ku toho v̌̌eho jako výrazně poškozuje.

Filipův postoj $\mathrm{k}$ online výuce je $\mathrm{z}$ výpovědi zřejmý - neumožňuje sdílet a rozvíjet interpretace jednotlivých studentů, což představuje významnou překážku pro vyučování a učení.

Co je dále podstatné: ovlivňování myšlení nesměřuje pouze od učitelů ke studentům, ale také naopak. Boris to popisuje takto:

Já mám totiž, ted'ka takovou velkou misi poslednich nèkolik let, a to je jako prostě vlastně našim studentuim vysvètlit, že ten jako jejich, i kdyそ̌ jako nezkušený hlas, je vlastné jako velice dưležitý jako v každý tý diskuzi... Já strašně rád na tèch jako seminárích zabredávám vlastnè jako do oblastí, o keterých jsem nikdy predtím neprémýšlel, a tèm studentuim to dávám vědèt, jo, že prostě ríkám, hele to jsem ještě nikedy neslyšlel, možná to je úplná blbost, ale jako pojd’me to zkusitjako spolu jako rozvinout, a ted' tam prostě faket jako sedím a tréba dvě minuty dumám prostě jako a škrábu se u toho teda na hlavè.

$\mathrm{V}$ této výpovědi opět vidíme důraz na zapojování studentů do diskuse, přičemž se explicitně zdůrazňuje váha a důležitost jejich hlasu při konstruování znalostí („pojd’me to zkusit jako spolu jako rozvinout“). Výše jsme uvedly, že se autentisté chápou jako tvůrci vědění, zde se vyjevuje, že vyučování je pro ně arénou, kde může vědění vznikat a přetvářet se, a to v živé spolupráci se studenty, kteří mohou být $\mathrm{v}$ tomto ohledu učitelům ceněnými partnery. Zároveň je však třeba podotknout, že takováto kolegiální živá tvorba nenastává podle autentistů ve výuce vždy. Pokud k tomu nedochází, znamená to pro autentisty zklamání.

Na rozdíl od funkcionalistů, kteří agilně prozkoumávají různé intearkční formáty a experimentují s jejich možnostmi, autentisté apriorně předpokládají, že technologie jsou vůči jejich způsobu výuky kontradiktorní. Tedy nějakým způsobem vedou online výuku, ale nemají od ní velká očekávání. To je $\mathrm{v}$ zásadě vede $\mathrm{k}$ tomu, že diskusi vzdávají a nahrazují ji monologickým výkladem, jak prriznává Filip: „Suma sumárum ta online výuka pro mě př́i- 
nesla víc takový ten frontální způsob povídání s nimi.“Výše popsaná absence plurality myšlení v online výuce vysvětluje, proč autentisté rezignují a konstruují online výuku oproti kontaktní slovy Filipa jako více „frontální “ či slovy Lea jako „hierarchičtější‘, tedy výrazně více zaměřenou na učitele než sami považují za žádoucí.

Vedle toho se v datovém materiálu objevil ještě jeden signifikantní rys, a to je omezení interaktivity na úzkou skupinu studentů, s nimiž učitel komunikuje velmi intenzivně, často ve formátu jeden na jednoho. Václav to komentuje:

Jájsem vlastnè zadával do IS úkoly, umistoval jsem tam nèjaké texty a dal jsem tam væ̌dycky otázky ke tomu. A ty otázky mèly být kontrolni, že nejdrív jsem je to nechal zpracovat, a pak jsem jim položil kontrolni otázky, řekl jsem jim, jestli dokážete odpovédèt na tyto otárky, takjste ten text pochopili. Pokud jste na né nedokázali, tak prosim vás, hned mně pište. Vypadalo to nakonec tak, že já jsem psal každý drubý den studentuim a ve dvou prípadech ze sedmdesáti šesti, shodou okolností to byly studentky, tak to fungovalo fantasticky. Jo, ono se ukázalo, ̌̌e prosté ve chvíli, kedy to jde, kedy tam je ta motivace, tak opravdu to byly úžasné dialogy, co jsme vedli jako pres maily, jo, velmi obsáblé a mè to vyslovené naplñovalo, to byly treba jako hodinu, ̌̌e jsem treba psal odpovéd' dloubou, proto že to byly opravdu fundované dotazy, mél jsem z toho obrovskou radost.

Vidíme radost učitele z bohatého a stimulujícího dialogu se studenty, kterému neváhá věnovat velké množství času. Zároveň však vidíme omezení tohoto způsobu práce na pouhé dvě studentky z původní velké skupiny. Současně je výmluvné, že ačkoli měli učitelé na FF MU v době pandemie $\mathrm{k}$ dispozici rozsáhlý technologický rezervoár spolu s podporou od specializovaného e-learningového oddělení, pokud autentisté v pandemii udržovali bohatou komunikaci se studenty, využívali spiše tradičnější formy - v př́ipadě Václava šlo o výměnu mailů.

\section{Diskuze a závěr}

Cílem této studie bylo popsat, jak učitelé přistoupili k nouzové distanční výuce za pomoci digitálních technologií v době, kdy měli omezený prostor pro zvažování a plánování výukových strategií, stejně jako pro rozvoj vlastních technologických a pedagogických kompetencí (Cameron-Standerford et al., 2020; Scherer et al., 2021).

Ukázaly jsme, že přístup učitelů $\mathrm{k}$ výuce $\mathrm{v}$ době pandemie silně souvisel s jejich pojetím výuky a s jejich chápáním dobré vysokoškolské výuky. Rozlišily jsme dva polární typy učitelů. Prvním typem jsou funkcionalisté, kteří výuku chápou především jako předávání znalostí a dovedností od učitele ke studentům. Provádějí průběžnou pedagogickou analýzu výukové situa- 
ce a potřeb studentů, stanovují si dílčí cíle a monitorují jejich dosahování. V pandemické době se jejich základní strategií stalo vytváření e-kopie výuky, kdy se ke všem složkám své běžné prezenční výuky snažili nalézt online ekvivalent a uvést jej do chodu. Základem je přitom vytváření kvalitních výukových materiálů a jejich distribuce ke studentům. Tito učitelé považují omezení prúmé interakce mezi učitelem a studenty za hlavní nevýhodu distanční výuky, a to proto, že se tím komplikuje poskytování zpětné vazby studentům a řízení jejich učení učitelem.

Druhým identifikovaným typem jsou autentisté, kteř́i výuku chápou jako vytváření znalostí a dovedností v procesu autentické komunikace mezi učitelem a studenty. Tito učitelé se domnívají, že e-kopie výuky je nemožná, naopak snahy o ni mohou mít paradoxní účinky. Technologie vnímají jako něco, co fixuje a zakonzervovává znalosti v určitém stádiu a znemožňuje jejich vývoj. Naopak autentickou interakci mezi přemýšlejícími jedinci technologie podle autentistů neumožňují, což tyto učitele vede ke skepsi a k regresu do tradičnějších didaktických forem, než jaké uplatňovali ve výuce tváří v tvár̆.

Nabízí se otázka, jak námi identifikované typy vztáhnout k nálezům jiných výzkumníků. V literatuře se objevuje spojení mezi konstruktivistickým a na studenty orientovaným př́istupem a entuziasmem při využívání technologií (Ertmer et al., 2015; Liu et al., 2020). Naopak odstup od technologií bývá ztotožňován s tradičnějším pojetím výuky orientovaným na učitele (Englund et al., 2017). Naše data však tuto dělící linii nekopírují. Nelze říci, že by funkcionalisté přemýšleli o výuce více v konstruktivistickém duchu než autentisté. Ve funkcionalistickém pojetí mají být studenti aktivní, avšak především proto, aby si osvojili poznání, jehož správnost a aktuálnost garantuje učitel. Pro studenty tito učitelé připravují řadu kreativních a aktivizujících zadání, avšak primárně s cílem zabezpečit hladkou transmisi vědění. $K$ př́ipravě online výuky přistupují funkcionalisté velmi svědomitě a promyšleně, může však docházet k určité „formalizaci“" studentské aktivity, která je vynucována, aniž by byl zřejmý vyšší cíl, než je kvalitní osvojení př́edložené látky. Autentistům naopak jde o to, aby studenti přemýšleli, považují je za partnery při tvorbě poznání. V tomto ohledu je jejich pojetí výuky více konstruktivistické než pojetí funkcionalistů. Absentuje však u nich jemnější pedagogická analýza jak kýženého stavu společného přemýšlení a tvorby dosáhnout, v jejich podání je to něco magického, co nelze plně predikovat, plánovat a ovládat. Ve výsledku se zdá, že autentisté rezignují na hledání cest jak dosáhnout svých velmi obecně definovaných výukových cílů v rámci distanční online výuky, ztrácejí pocit učitelské sebeúčinnosti a nakonec s jistým fatalismem distanční výuku spíše skepticky komentují, namísto aby systematicky pracovali na jejím zlepšování. Distanční online výuka autentistů má, soudě podle jejich vlastních popisů, nakonec patrně méně konstruktivistických znaků než výuka funkcionalistů. 
Ve výzkumu profesního sebepojetí vysokoškolských učitelů Šed’ová et al. (2016) zjistili, že se někteří akademici vnímají více jako učitelé, jiní více jako výzkumníci, případně přisuzují oběma rolím stejnou váhu. V literatuře, která se věnuje kvalitě vysokoškolské výuky, se objevuje tvrzení, že silné zapojení do výzkumu, či přímo mírná preference výzkumu před výukou na straně učitele, vede k vyšší kvalitě výuky (Galbraith \& Merril, 2012; Mägi \& Beerkens, 2015; Trigwell, 2005). Nabízí se propojení těchto nálezů s naší typologií. Oba námi identifikované typy učitelů se od sebe liší konceptualizací učitele jako experta na určitý segment vědění (funkcionalisté) versus tvưrce vědění (autentisté). Nabízí se proto hypotéza, že se autentisté cítí více ukotveni ve výzkumnické roli a funkcionalisté více v roli učitelské. Doplňkové dotazníky, které jsme respondentům distribuovaly, však pro tuto možnost nesvědčí. Autentisté téměř unisono uváděli, že oběma rolím přisuzují stejnou váhu, také jim obě tyto role př́nášejí srovnatelné uspokojení. Naopak funkcionalisté reportovali celé spektrum profesní identity: někteří se situovali do učitelské role, jiní do role vědecké a stejně tak byla u nich zastoupena pozice na pomezí. Zdá se tedy, že sebepojetí (učitel versus výzkumník) neimplikuje prrímo pojetí výuky. Někteří akademici, kteři se vnímají primárně jako výzkumníci, postupují při plánování a realizaci výuky přísně funkcionalisticky. Jiní funkcionalisté se (vcelku očekávatelně) rekrutují z řad akademiků, kteří se vnímají především jako učitelé. Autentisté jsou však vcelku homogenní $\mathrm{v}$ tom, že obě role organicky slučují, chápou tedy výuku a výzkum jako synergicky propojené oblasti.

V souladu s nálezy jiných autorů získaných před i v průběhu pandemie (viz např. Heinonen et al., 2019; Naylor \& Nyanjom, 2020; Ramlo, 2021) konstatujeme, že učitelé jsou ve svém vztahu k technologiím diverzifikovaní, přičemž škála sahá od fascinace technologiemi až po jejich odmítání. Studie prováděné v pandemii ukázaly, že předchozí zběhlost v užívání technologií pozitivně ovlivnila zvládání přechodu na nouzovou distanční výuku (Marek et al., 2021; Scherer et al., 2021). Na tomto místě je třeba připomenout, že kompetence nutné $\mathrm{k}$ implementaci technologií jsou tvořeny dvěma subkompetencemi - učitelé musí na jedné straně umět obsluhovat techniku, ovládat aplikace, na druhé straně musí být $\mathrm{s}$ to tyto dovednosti vztáhnout ke svým pedagogickým cílům (Almerich et al., 2016). Pokud se tyto dvě složky propojí a navážou na expertízu učitele v jeho disciplinárním poli, disponuje učitel tím, co bývá označováno jako technologicko-pedagogická znalost obsahu (Mishra \& Koehler, 2006). Teprve v takovém okamžiku je učitel s to funkčně integrovat technologie do své výuky. Naše data svědčí o tom, že samotná uživatelská kompetence nepředstavuje pro učitele velký problém, a dokonce se $\mathrm{v}$ tomto směru od sebe př́liš neliší funkcionalisté od autentistů. Problém představuje kompetence pedagogická. O té můžeme říci, že je rozvinutější u funkcionalistů, kteř́i jsou schopni analyzovat své didak- 
tické cíle a hledat pro ně funkční techologické nástroje. Naopak autentisté ponechávají obě složky odděleny, chybí jim představa o tom, jak by mohli svoji technologickou zběhlost využít pedagogicky.

Zastavme se nyní u otázky, zda mohou mít technologie ve vztahu k vysokoškolské výuce transformační potenciál (Liu et al., 2020). Přes určitou skepsi (Porter \& Graham, 2016; Schneckenberg, 2009) existují některé empické doklady, že by tomu tak mohlo být. Výzkum Jääskelä et al. (2017) ukázal, že učitelé pokročilí v pedagogické implementaci technologií je vnímají jako nástroj obohacení v mnoha oblastech - od individualizace studia, přes kreativní práci ve skupinách až po posilování autonomie studentů. Jinými slovy pokročilí učitelé chápou technologie jako nástroj pro pozitivní změnu v kultuře vyučování a učení.

Naše data však nenasvědčují tomu, že by pandemická doba byla učiteli na FF MU uchopena jako př́íležitost k transformaci. Funkcionalisté sice technologie svědomitě a uvážlivě integrovali, jejich hlavní strategií však byla e-kopie výuky. To znamená, že se snažili o to, aby distanční online výuka byla co možná nejpodobnější výuce prezenční. Nešlo jim tedy o proměnu výuky; změny, které zaznamenali a ex post je hodnotí pozitivně (časová flexibilita, rozšíření zdrojů), jsou spíše drobné. Autentisté si transformační potenciál uvědomili, avšak potenciální změnu vyhodnotili jako nebezpečnou a ohrožující kvalitu vysokoškolského vzdělávání a zaujali vůči ní záměrně rezistentní postoj.

Naše závěry rozhodně neznamenají, že by se učitelé na FF MU nesnažili o to, aby jejich výuka byla kvalitní. Jejich výroky - včetně těch vyjadřujících obavy ze změn - jsou rozumné a legitimní. Jde spíše o to, že se jejich úsilí o kvalitu neprotíná s trendem $\mathrm{k}$ technologizaci výuky. Technologie jsou pro ně zvládnutá výzva (funkcionalisté), př́ípadně nutné zlo (autentisté), nikoli dar z nebes. Zároveň je ovšem třeba vzít v potaz, že naše data reflektují období velmi náročné pro všechny zúčastněné, kdy přechod k distanční online výuce probíhal vynuceně a pod tlakem. Je možné, že kdyby měli učitelé $\mathrm{k}$ dispozici více času a podpory, pozitivní transformační potenciál technologií by se projevil. Ve chvíli, kdy dokončujeme tento text, pandemie stále trvá a vysoké školy vyučují distančně. Navíc $\mathrm{v}$ budoucnosti se podobná situace může z různých důvodů opakovat. Je tudíž jednoznačné, že potřebujeme důsledné zkoumání toho, jak podpořit vysokoškolské učitele, aby technologickou výzvu nejen zvládli, ale aby z ní vytěžili pro sebe i pro své studenty to nejlepší. 


\section{Literatura}

Almerich, G., Orellana, N., Suárez-Rodríguez, J., \& Díaz-García, I. (2016). Teachers’ information and communication technology competences: A structural approach. Computers \& Education, 100, 110-125. https://doi.org/10.1016/j.compedu.2016.05.002

Bain, K. (2004). What the best college teachers do. Harvard University Press.

Bozkurt, A., \& Sharma, R. C. (2020). Emergency remote teaching in a time of global crisis due to CoronaVirus pandemic. Asian Journal of Distance Education, 15(1), 1-6. https://doi. org $/ 10.5281 /$ zenodo.3778083

Cameron-Standerford, A., Menard K., Edge C., Bergh B., Shayter A., Smith K., \& VandenAvond L. (2020). The phenomenon of moving to online/distance delivery as a result of COVID-19: Exploring initial perceptions of Higher Education Faculty at a Rural Midwestern University. Frontiers in Education, 5, 1-11. https://doi.org/10.3389/feduc.2020.583881

Cutri, R. M., Mena, J., \& Whiting, E. F. (2020). Faculty readiness for online crisis teaching: Transitioning to online teaching during the COVID-19 pandemic. European Journal of Teacher Education, 43(4), 523-541. https://doi.org/10.1080/02619768.2020.1815702

Devlin, M., \& Samarawickrema, G. (2010). The criteria of effective teaching in a changing higher education context. Higher Education Research \& Development, 29(2), 111-124. https:// doi.org/10.1080/07294360903244398

Downing, J., \& Dyment, J. E. (2013). Teacher educators' readiness, preparation, and perceptions of preparing preservice teachers in a fully online environment: An exploratory study. Teacher Educator, 48(2), 96-109. https://doi.org/10.1080/08878730.2012.760023

Duschinská, K., \& High, R. (2020). Reflexe nouzové výuky: distanční přednášky předmětu základy didaktiky. Pedagogická orientace, 30(2), 266-281. https://doi.org/10.5817/ PedOr2020-2-266

Englund, C., Olofsson A. D., \& Price, L. (2017). Teaching with technology in higher education: Understanding conceptual change and development in practice. Higher Education Research \& Development, 36(1), 73-87. https://doi.org/10.1080/07294360.2016.1171300

Ertmer, P. A. (2005). Teacher pedagogical beliefs: The final frontier in our quest for technology integration? Educational Technology Research and Development, 53(4), 25-39. https://doi. org/10.1007/BF02504683

Ertmer, P. A., Ottenbreit-Leftwich, A., \& Tondeur, J. (2015). Teacher beliefs and uses of technology to support 21 st century teaching and learning. In H. R. Fives \& M. Gill (Eds.), International handbook of research on teacher beliefs (pp. 403-418). Routledge, Taylor \& Francis.

Fritzová, M. (2020). Kvalita distanční výuky na katedrách a ústavech historie v době covid-19. Pedagogická orientace, 30(2), 255-265. https://doi.org/10.5817/PedOr2020-2-255

Galbraith, C. S., \& Merril, G. B. (2012). Faculty research productivity and standardized student learning outcomes in a university teaching environment: A Bayesian analysis of relationships. Studies in Higher Education, 37(4), 469-480. https://doi.org/10.1080/0307507 9.2010 .523782

Hativa, N., Barak, R., \& Simhi, E. (2001). Exemplary university teachers: Knowledge and beliefs regarding effective teaching dimensions and strategies. The Journal of Higher Education, 72(6), 699-729. https://doi.org/10.2307/2672900

Heinonen, K., Jääskelä, P., Häkkinen, P., Isomäki, H., \& Hämäläinen, R. (2019). University teachers as developers of technology-enhanced teaching-Do beliefs matter? 
Journal of Research on Technology in Education, 51(2), 135-151. https://doi.org/10.1080/1539152 3.2018.1564894

Jääskelä, P., Häkkinen, P., \& Rasku-Puttonen, H. (2017). Teacher beliefs regarding learning, pedagogy, and the use of technology in higher education. Journal of Research on Technology in Education, 49(3-4), 198-211. https://doi.org/10.1080/15391523.2017.1343691

Kember, D., \& Kwan, K. (2000). Lecturers' approaches to teaching and their relationship to conceptions of good teaching. Instructional Science, 28(5), 469-490. https://doi. org/10.1023/A:1026569608656

Koubek, P. (2018). Portrét myšlení a jednání učitelek občanské výchovy: Vícečetná případová studie subjektivních teorií učitelek o didaktické transformaci. Pedagogika, 68(2), 130-154. https://doi.org/10.14712/23362189.2017.1014

Krátká, J., \& Zemanová, L. (2020). Distanční výuka na druhou. Pedagogická orientace, 30(2), 249-254. https://doi.org/10.5817/PedOr2020-2-249

Liu, Q., Geertshuis, S., \& Grainger, R. (2020). Understanding academics' adoption of learning technologies: A systematic review. Computers and Education, 151, 1-19. https://doi. org/10.1016/j.compedu.2020.103857

Lowman, J. (1995). Mastering the techniques of teaching. Jossey-Bass.

Mägi, E., \& Beerkens, M. (2015). Linking research and teaching: Are research-active staff members different teachers? Higher Education, 72(4), 1-18. https://doi.org/10.1007/s10734015-9951-1

Marek, K. (2009). Learning to teach online: Creating a culture of support for faculty. Journal of Education for Library and Information Science, 50(4), 275-292. https://www.jstor.org/ stable/40732589?seq=1\#metadata_info_tab_contents

Marek, M. W., Chew, C. S., \& Wu, W.-C. V. (2021). Teacher experiences in converting classes to distance learning in the covid-19 pandemic. International Journal of Distance Education Technologies, 19(1), 89-109. https://doi.org/10.4018/IJDET.20210101.oa3

Mareš, J., Slavík, J., Svatoš, T., \& Švec, V. (1996). Učitelovo pojetí výuky. Masarykova univerzita.

McQuiggan, C. (2007). The role of faculty development in online teaching's potential to question teaching beliefs and assumptions. Online Journal of Distance Learning Administration, 10(3). http://www.westga.edu/ distance/ojdla/fall103/mcquiggan103.htm

Mishra, P., \& Koehler, M. J. (2006). Technological pedagogical content knowledge: A new framework for teacher knowledge. Teachers College Record, 108(6), 1017-1054. https://doi. org/10.1111/j.1467-9620.2006.00684.x

Naylor, D., \& Nyanjom, J. (2020). Educators' emotions involved in the transition to online teaching in higher education. Higher Education Research \& Development, 1-15. https://doi.or $\mathrm{g} / 10.1080 / 07294360.2020 .1811645$

Podolská, V. (2021). Studium v době koronavirové krize očima vysokoškolských studentů. [Bakalářská diplomová práce, ÚPV FF MU]. Archiv závěrečných prací MUNI. https://is.muni.cz/ auth/th/qw1xn/

Porter, W. W., \& Graham, C. R. (2016). Institutional drivers and barriers to faculty adoption of blended learning in higher education. British Journal of Educational Technology, 47(4), 748-762. https://doi.org/10.1111/bjet.12269

Ramlo, S. (2021). The coronavirus and higher education: Faculty viewpoints about universities moving online during a worldwide pandemic. Innovative Higher Education, 46, 1-19. https:// doi.org/10.1007/s10755-020-09532-8 
Scherer, R., Howard, S. K., Tondeur, J., \& Siddiq, F. (2021). Profiling teachers' readiness for online teaching and learning in higher education: Who's ready? Computers in Human Behavior, 118, 1-16. https://doi.org/10.1016/j.chb.2020.106675

Schneckenberg. D. (2009). Understanding the real barriers to technology-enhanced innovation in higher education. Educational Research, 51(4), 411-424. https://doi.org/10.1080/ 00131880903354741

Strauss, A., \& Corbinová, J. (1999). Základy kvalitativního výzkumu: postupy a techniky metody zakotvené teorie. Albert.

Šed’ová, K., Švaříček, R., Sedláčková, J., Čejková, I., Šmardová, A., Novotný, P., \& Zounek, J. (2016). Pojetí výuky a profesní identita začínajících vysokoškolských učitelů. Studia paedagogica, 21(1), 9-34. http://dx.doi.org/10.5817/SP2016-1-2

Švaříček, R., \& Šed’ová, K. (2007). Kvalitativni výzkum v pedagogických védách. Portál.

Trigwell, K. (2005). Teaching-research relations, cross-disciplinary collegiality and student learning. Higher Education, 49(3), 235-254. https://doi.org/10.1007/s10734-004-6665-1

Trigwell, K., \& Prosser, M. (1996). Changing approaches to teaching: A relational perspective. Studies in Higher Education, 21(3), 275-284. https://doi.org/10.1080/03075079612331381211

Weber, M. (2009). Metodologie, sociologie a politika. Oikoymenh.

\section{Kontakt na autorky}

Klára Šed’ová

Ústav pedagogických věd, Filozofická fakulta, Masarykova univerzita

E-mail:sedova@phil.muni.cz

Barbora Nekardová

Ústav pedagogických věd, Filozofická fakulta, Masarykova univerzita

E-mail: nekardova@mail.muni.cz

Katarína Rozvadská

Ústav pedagogických věd, Filozofická fakulta, Masarykova univerzita

E-mail: rozvadska@phil.muni.cz

\section{Corresponding authors}

Klára Šed’ová

Department of Educational Sciences, Faculty of Arts, Masaryk University

E-mail:sedova@phil.muni.cz

Barbora Nekardová

Department of Educational Sciences, Faculty of Arts, Masaryk University

E-mail: nekardova@mail.muni.cz

Katarína Rozvadská

Department of Educational Sciences, Faculty of Arts, Masaryk University

E-mail: rozvadska@phil.muni.cz 
